\title{
The role of clinical pilates exercises in children with juvenile idiopathic arthritis: a pilot study
}

\author{
Edibe Unal ${ }^{1 *}$, Pinar Dizmek ${ }^{1}$ Yelda Bilginer ${ }^{2}$, Asli Celebi Tayfur ${ }^{2}$, Nesrin Besbas $^{2}$, Seza Ozen² \\ From 18th Pediatric Rheumatology European Society (PReS) Congress \\ Bruges, Belgium. 14-18 September 2011
}

\begin{abstract}
Background
Juvenile İdiopathic Arthritis(JIA) affects the quality of life to a significant degree causing the child to become less social.The family puts on an overprotective attitude. The importance of exercise is remarkable in these children. Clinical Pilates Exercises don't generate fatigue and help inhibition of pain with respiratory control. This exercise is entertaining, and can be applied as a group. Even though pilates is used on adult rheumatic patients, there is no study in JIA.
\end{abstract}

\section{Aim}

To investigate the effects of Clinical Pilates Exercises on functional status,pain level, and general health perception in children with JIA.

\section{Methods}

The study included 23 children(14F;9M) with JIA. After obtaining demographics, Time-up\&Go test (TUG), Time to go\&back $(10 \mathrm{~m})(\mathrm{GGT})$, the number of Sit-Stand up in 30 seconds, FACES Pain Scale, the child, family and physiotherapist global assesment Visual Analogue Scale (VAS), Childhood Health Assessment Questionnaire (CHAQ) was performed in all. Sedimentation rate (ESR) and $C$-reactive protein(CRP) were recorded. The same assessments were repeated after treatment. Therapy sessions were done thrice a week. The session included warm-ups, the main workout and cool down. The exercises consisted of clinical pilates exercises,dancing and body image affirmation exercises.

\section{Results}

The mean age was $11,46 \pm 2,84$ years. The mean duration of disease was $4,75 \pm 2$,2years. 13 oligoarticuler and 10 polyarticular type JIA included. After the treatment,

${ }^{1}$ Hacettepe University,Faculty of Health Science, Ankara, Turkey

Full list of author information is available at the end of the article there were significant improvements in the Sit-Stand up test, FACES, ESR, CRP, the child and physiotherapist global assesment VAS scores $(P<0,05)$. TUG, GGT, CHAQ, the family global assesment VAS scores didn't change significantly $(\mathrm{P}>0,05)$.

\section{Conclusion}

Clinical pilates exercises have shown positive effects on decreasing the pain, improving function and general health preception. Clinical Pilates Exercises can be considered as reliable exercise model in children with JIA.

\section{Author details}

${ }^{1}$ Hacettepe University,Faculty of Health Science, Ankara, Turkey. ${ }^{2}$ Hacettepe University, Faculty of Medicine, Ankara, Turkey.

Published: 14 September 2011

doi:10.1186/1546-0096-9-S1-P117

Cite this article as: Unal et al:: The role of clinical pilates exercises in children with juvenile idiopathic arthritis: a pilot study. Pediatric

Rheumatology 2011 9(Suppl 1):P117.

Submit your next manuscript to BioMed Central and take full advantage of:

- Convenient online submission

- Thorough peer review

- No space constraints or color figure charges

- Immediate publication on acceptance

- Inclusion in PubMed, CAS, Scopus and Google Scholar

- Research which is freely available for redistribution
C Biomed Central

(0) 2011 Unal et al; licensee BioMed Central Ltd. This is an open access article distributed under the terms of the Creative Commons Attribution License (http://creativecommons.org/licenses/by/2.0), which permits unrestricted use, distribution, and reproduction in any medium, provided the original work is properly cited. 